grants from the National Institutes of Neurological Diseases and Blindness, US Public Health Service.

\section{H. RIPPS}

Department of Ophthalmology,

New York University School of Medicine,

550 First Avenue,

$\mathrm{NY} 10016$.

\section{R. A. Weale}

1)epartment of Physiological Optics,

Institute of Ophthalmology,

Judd Street,

Loudon WC1.

Received January 28; revised April 2, 1969.

1 Ripus, H., and Weale, R. A., J. Physiol., 173, 57 (1964).

' ('arr, R. E., and Ripps, H., Invest. Ophthal., 6, 426 (1967).

${ }^{3}$ Weale, R. A., Brit. J. Ophthal., 41, 461 (1957).

' Bridges, C. D. B., Biochem. J., 79, 135 (1961).

Baumann, C., Pfiügers Arch., 298, 61 (1967).

' Ripns, H., and Weale, R. A., J. Physiol.,200, 151 (1969).

: liips. H., and Weale, R. A., J. Physiol., 196, 67 (1968).

- Weale, R. A., Vis. Res., 2, 25 (1962).

Wiale, R. A., Vis, Res., 7, 819 (1967)

" Lythgoe, R. J., J. Physiol., 89, 331 (1937).

"Ostroy, S. E., Erhardt, k., and Abrahianson, E. W., Biochem. Biophys. tcta, 112, 265 (1966).

12 Frank, R. N., and Dowling, J. F., Science, 161, 487 (1968).

${ }^{13}$ librey, T., Vis. Res., 8, 965 (1968).

"tone, R. A., and Cobbs, W. H., Nature, 221, 820 (1969).

': Wald, G., and Brown, P. K., Science, 127, 222 (1958).

16 Matthews, R. G., Hubbard, R., Brown, P. K., and Wald, (i., J. Gem. Physiol., 47, 215 (1963)

\section{Cholesterol in the Cuticular Wax of Boophilus microplus}

T'RACEs of substances giving colour reactions typical of stcrols have been found in the cuticle and cuticular wax of sereral arthropods ${ }^{1-6}$, but they have not been reported from ticks ${ }^{7,8}$. I have now shown that both free and esterificd cholesterol occur in the wax of Boophilus microplus, and I have measured the quantity of each present.

Wax was obtained by washing recently engorged adult female ticks with hexane in standard conditions ${ }^{9}$. Thin layer chromatography was carried out in the solvent system benzene : ethyl acetate $5: 1$; the dried plates were sprayed with 50 per cent sulphuric acid and heated at $110^{\circ} \mathrm{C}$. Magenta pink colour devcloped in two spots the $R_{F}$ values of which corresponded to those of free and esterified cholesterol, and elution of corresponding areas of unsprayed plates yielded material with the infrared spectra of these substances. Free and total cholesterol were quantitatively determined colorimetrically 10,11.

In five samples of wax, free cholesterol lay between $0 \cdot 8$ and $0.9 \mu \mathrm{g}$ per tick, and total cholesterol between 3.2 and $3.8 \mu \mathrm{g}$. Thus approximately $2.6 \mu \mathrm{g}$ was present in the csterified form. Cholesterol itself accounts for approximately 17 per cent of the total weight because the cuticle wax of the newly engorged female weighs $20 \mu \mathrm{g}$ (ref. 9). The identity of the fatty acids involved in the ester linkage is not known, but if Gilby's ${ }^{8}$ estimate of an average chain length of $\mathrm{C}_{30}$ is taken for calculation of the weight of cholesterol ester present, free and esterified cholesterol together make up 32 per cent of the wax.

This high proportion was unexpected, because although it has been suggested that sterols may be common constituents of cuticle wax ${ }^{12}$, they have not been proposed as major constituents. Cuticle wax provides the main barrier to the passage of water across the tick cuticle', but whether sterols are among the components necessary for the maintenance of the water proofing structure is not known; sterols in this quantity are certainly not involved in other arthropods. It has been suggested that in $B$. microplus cuticle wax may act as a vehicle for the removal of lipid-soluble material derived from the food ${ }^{9}$. Cholesterol was therefore determined in wax from females: weighing about $15 \mathrm{mg}$, still feeding on the host but before final engorgement, and from fomales at the perk of egg laying, several days after dropping from the host. 'T'otal cholesterol values were 3.5 and $3.0 \mu \mathrm{g}$ per tick respectively: thus neither engorgement nor the rapid digestion of food which accompanies egg production had increased the quantity already present.

Clearly the origin of the cholesterol and the timing of its secretion must be investigated before any attempt can bc made to account for its presence. No information on the ability of acarines to synthesize sterols appears to be available. It is accepted, however, that inscets, and probably crustaceans ${ }^{13}$, are unable to do so. If it is assumed that extensive synthesis by $B$. microplus is unlikely, the cholesterol in the wax must have been derived from the food. B. microplus passes through larval, nymphal and adult stages on the same host, the fermale adult increasing in weight from $2 \mathrm{mg}$ to $15 \mathrm{mg}$ over a period of 5 to 6 days after attachment, and then to $150.200 \mathrm{mg}$ during a final period of about $24 \mathrm{~h}$ rapid engorgement ${ }^{14}$. From estimates of the quantity of erythrocytes and plasma obtained by the various stages ${ }^{15}$, it can be calculated that about $1 \mu \mathrm{g}$ cholesterol is ingested during larval and nymphal feeding, and about 10 kg during adult growth to $15 \mathrm{mg}$. Possible lisses during larval and nymphal stages are unknown. These estimates of intakt are probably too low, because the diet also includes components of the epidermis and upper dermal tissue and large numbers of leucocytes ${ }^{16}$, all of which have a (e)1siderable cholesterol content ${ }^{17,18}$. It does seem, however. that the cholesterol secreted into cuticle wax may- represent a significant proportion of that ingested during carly" adult growth, the proportion being higher the earlier the secretion takes place.

Arthropods using mammalian blood and skin tissues as food inevitably obtain quantities of cholesterol much greater than those regarded as essential in the diet ${ }^{12}$. The uses to which they put this excess, and the routes by which they dispose of it, have not been investigated to any extent. It would be interesting to know whether significant sccretion into cuticle wax occurs in other bloodsucking species and, if so, whether this ability can be further correlated with habits of feeding, excretion or egglaying.

\section{LOIS M. C'HERRY}

CSIRO, Division of Entomology,

Long Pocket Laboratories,

Indooroopilly,

Queensland.

Received February 11; revised March 25, 1969.

'Dennell, R.. and Malek, S. R. A., Proc. Roy. Soc., B, 143, 41+ (1955).

${ }^{2}$ Sewell, M. 'T., Ann. Ent. Soc. Amer., 48, 107 (1955).

${ }^{3}$ Sewell, M. T., Quart. J. Microsc. Sci., 96, 73 (1955).

4 Gilhy, A. R., and Cox, M. E., J. Insect. Physiol., 9, 671 (1963).

"Haker, G., Pepper, J. H., Johnson, L. IJ., and Hastings, H.. J. Insect. Physiol., 5, 47 (1960).

${ }^{6}$ Bursell, E., and Clements, A. N., J. Insert. Physiol., 13. 1671 (1967).

"J Jees, A. D., and Beament, J. W. L., Quart. J. Mirrosc. Sici., 89. 291 (1948).

${ }^{8}$ Gilby, A. R., Arch. Biochem. Biophys., 67, 320 (1957).

" ('herry, L. M., J. Exp. Biol. (in the press).

in Beale, R. N., and Croft, D., J. Clin. Path., 15, 221 (1962).

" ('herry. T. M., J. Chromatog. (in the press).

12 ('layton, R. B., .J. Lipid Res., 5, 3 (1964).

13 Tandee, 1). 1., Nature, 195, 814 (1962).

"Wharton, R. H., and Ctech, K. B. W.. Prore. Second Intrin. Comg. Acarol. (in the press).

is Seifert, G. W., Springell, P. H., and Tatehell, R. J., Parasitology. 58, 415 (1968).

${ }^{16}$ Tatchell, R. J., and Moorhouse, D. F., Purasitology, 58. 441 (1968).

17 Hoyd, E. M., J. Biol. Chem., 101, 623 (1933).

${ }^{18}$ Koppenhoefer, R. M., J. Biol. Chem., 116, 321 (1936). 